PESHAWAR JOURNAL OF PSYCHOLOGY AND BEHAVIORAL SCIENCES, 2018, VOL. 4, NO. 1, 97-120

\title{
Pakistani Media and Its Positive Effects: The Study of Children Selected Cartoons
}

\author{
Sarwat Rahman ${ }^{1}$ \\ Fatima Jinnah Women University, Rawalpindi
}

Pakistani media has tried to present positive themes for the children of the country. The country has seen terrorism which affected every field of life and the country law and order situation was at stake. The upbringing of children in such a situation is very dangerous as they are getting only negative messages from the society. The media has a great quality to influence the mind of the growing, even mature, children. There is a dire need of some campaign to break the negative atmosphere and divert the attention of children towards the positive aspects of life. The three cartoon programs Quaid Say Baatain (2013), Burka Avenger (2013), and 3 Bahadur (2015) have done a great job. The researcher will analyze these three cartoon programs in the light of Social Action theory by Anderson and Meyer and Cultivation Theory by George Gerbner. The purpose of the study is to bring to light the positive image of the Pakistani society through media.

Keywords: Pakistani media, cartoon programs, social action theory, cultivation Theory.

"Media studies starts from the observation that media now permeate almost every moment of our existence. There almost nothing that we do that escape mediation" (Press and Williams as quoted in Media Studies: The Bascis, 2012).

The subordination of our cultural and daily lives to the mass media have been one of the notable changes in our social environment in $20^{\text {th }}$ and

\footnotetext{
ISSN 2415-6779 EISSN 2518-4474

https://doi.org/10.32879/picp.2018.4.1.97

www.pjpbsicp.com
}

${ }^{1}$ M.Phil Scholar, Fatima Jinnah Women University, Rawalpindi 
$21^{\text {st }}$ Centuries. (Huesmann, 2007, para. 2) That is why it will not be wrong to say that radio, television; video games and cell phones have assumed a central position in the lives of children, not only of other countries but, of Pakistan and have great impact on the belief and behavior of the children of the country.

Along with the other programs children prefer to watch cartoons. Felix the Cat is the first favorite cartoon of children which was famous in 1920s. After this, there started a different cartoons programs like Mickey Mouse, Pluto and Donald Duck etc which became famous among children. Hassan and Daniyal in their research about Cartoon Network (1992) and the effect of it on the behavior of the children, came up with the results that there existed a strong relation between watching cartoon programs and the behavior of children and the results were similar to the study of Clara and Marian (1980s) that children liked cartoon and imitated the behavior they observed on television. According to Hassan and Daniyal 55\% children liked to fight with their classmates as they watch cartoons with fighting and turmoil in it like Tom and Jerry. (p.8-10).

Qayyum, Malik, Iqbal, Anwar and Sohail (2013) in their research "Exposure to Violent TV Programs and Its Effects on Siblings Aggressive Behavior: Parent's Perceptions" found that "there is no relation between television exposure and the aggressive behavior in breaking things. So the researchers concluded that there may be some other reasons that became the cause of children aggressive behavior" (p.212). This shows that along with media other factors also leave impression on the behavior of the children but as the media influence is considered to be great, the positive and constructive contents on the media can leave a positive impression or lessen the surrounding negative environment. The present study also aims to find the positive role of media due to its cultivation ability and the study also aims to find the presence of active or passive viewers.

\section{Method}

Research Methodology provides a way for the systematic study of a required problem and helps the researcher to remain on the track and find the answer to the researchable problem within the limits of the methodology. This research on the influence of media on children in Pakistan is done under the paradigm of interpretivism. As compared to the Positivist and Post positivist claim that through empirical and logical reasoning truth can be found, Interpretivists believe that we cannot reach the truth but only near the truth. Due to this aspect of Interpretivism the 
research falls in the category of Qualitative Research, "At a basic level, qualitative research strives to understand the traditions, contexts, usages, and meanings of words, concepts and ideas" (Brennen, 2013, p.14). There are different kinds of qualitative research like narrative research, ethnographic research, and content analysis. The present research is based on content analysis. Media content analysis was started by Harold Lasswell for his study of propaganda theory. It became widely in use with the arrival of Television in 1950s. According to Neuman, Content analysis is a, "technique for gathering and analyzing the content of text. The 'content' refers to words, meanings, pictures, symbols, ideas, themes. Or any message that can be communicated. The 'text' is anything written, visual or spoken that serves as a medium of commination" (Macnamara, Media Content Analysis, Its Uses; Benefits and Best Practice Methodology, p.1-2). Shoemaker and Reese (1996) also support the claim that media content analysis can be qualitative by pointing towards the behavioristic and humanistic traditions. (p.4) "Qualitative Content Analysis looks for more general themes and in this way more closely resembles the analysis of interview data" (Priest, p.40).

For the thematic study three children programs have been selected. The three selected programs are 3 Bahadur (2015), Burqua Avenger (2013) and Quaid Say Baatain(2013). The selection is done by restricting the time from 2011 to 2015. It was decided to choose some recent programs. After the search the selected programs appeared the more recent.

The theoretical framework selected for the present thematic study is based on the Cultivation Theory of Gerbner and Social Action Theory of Anderson and Meyer. Cultivation theory which came after the hypodermic theories is a stalagmite theory. Stalagmite means "Slow buildup of formations on cake floors" (para.1). Gerbner, Dean of Annenburg Schools of Communications at the University of Pennsylvania, focus of the study is to see how television influence the perceptions of the viewers about the world. He claims that, "television has a long-term effects which are small, gradual, indirect but culminate and significant" (Cultivation Theory, para.1). According to him, "mass media cultivates attitudes and values which are already present in the culture. The media maintains and propagates these values amongst members of a culture, thus binding it together" and calls "mass media as a socializing agent" (Cultivation, para. 2; Gerbner, 1986, p.3-13).

Social Action theory on the other hand focuses on the active viewers and rejects the opinion of the cultivation theories of passive 
viewers. According to Anderson and Meyer (1988) in their book Mediated Communication: A Social Action Perspective viewers construct meanings from the messages of media and messages can be constructed in many ways according to the situation the viewers are living in (2009, para. 5).

In this way, it can be said that the media cultivate different ideas in the minds of the children. The ideas can be positive and negative depending on the aim of the cultivator. The effects of cultivation are gradual but long-term but it cannot be said that the viewers are accommodating the message as it is. The target groups are considered to be active and it is said that they interpret the message according to their surrounding situation. Viewers, therefore must not be neglected but the power of media cannot be undermined. Through the selected framework the positive influence of Pakistan media on the children will be studied and how the positive image of the country is portrayed.

\section{History of media}

Media in the present times has crossed the limits of space and time. In the olden time the "cave drawing and other representation of human experiences" could not be shared with large number of people in short time but the advancement in technology has beaten the time and space restrictions. (McDougall,2012, p.6)

In 1876 telephone was created and sound was able to be sent and received. In 1898 moving images came in the lives of people. This was an amazing invention and it is said that people were amazed and terrified to see the moving train coming towards them and were unable to distinguish between reality and imagination. "It takes 300 years to move from printing to photography" and only 80 years to develop moving film. So, it is a very recent invention that the Lumiere Brothers, a moving train film, Mass Media therefore begin with the printing press. (McDougall, 2012, p.51$53)$.

Until the late 1990s there was no connection between TV and computer but cinema since 1950s was feeling a threat from TV and VCR but IMAX and 3D and multiplex have changed the shape of cinema and recharged the audience to have the desire to see a film with family on big screen. (McDougall, J , 2012, p. 14-15).So, the "term "media" ... is linked to mass media in the eighteenth Century, paper was a medium of circulation, as was money; in the nineteenth Century, electricity was a medium; in the late nineteenth and twentieth Centuries, media emerged as the to describe inexpensive newspapers and magazines...became a 
singular noun...Friedrich Kittler himself does not engage in the etymology of media, his argument in Gramophone, Film and Typewriterthat these media displaced writing as the universal storage medium, maps nicely into the emergence of the term media" (Chun, 2006, p. 3). McLuhen is among the primary theorist to study the influence of media. He claimed about the media influence on the perceptions of viewers long before the arrival of new digital media. According to him "medium is the Message" (McDougall, J. 2012, p. 14-15).

Western Media was controlled by US and anti-Islam and antiMuslim news were at its peak especially after 9/11. According to John Galtung, "media projected violence without analyzing its cause for unresolved issues, portrays one side as evil and the other side as liberal". (Naseer, Katib, and Ejaz, 2010, p. 12) Ricahard Salient confess, "Our job is to give people not what they want, but we decide what they ought to know" (Naseer, Katib, and Ejaz, 2010, p. 12).

The time between World War I and World War II has been considered as the time of origin of mass communication in US and movie theater became popular. Payne Fund Studies were the first series of study about media and provided information about the effects of Hollywood on life styles of people but along with that there were other things which were including the life of young people that is automobile. Automobile was a means of escape from the supervision of parents. Along with this the urbanization and the migration of people to America resulted in a mobilized and diverse society. (Priest, p.37-38)

The second wave of communication research started as a result of Second World War. The successful propaganda of Nazi draws the attention of researchers. During the war media urged the citizens of U.S to help in the success of war. Frank Copra was especially recruited for this purpose and the effect of Rosie the Riveter cannot be undermined once women came out of their houses under the influence of the said character. There was no going back and media influence was questioned. (Priest, 2010, p.37-38)

The early media researchers assumed theoretically about the direct influence of media on politics and the behavior of viewers. They were of the opinion that only two parties are there the 'sender' and the 'receiver'. Sender is the supplier of information while receivers are the audiences. It was considered that the senders will decide the content of the media while the receivers will respond in the expected manner. The sender message and intention became important. This concept was rejected on the ground 
that the media study is not that much simple but it is complex in reality. According to them the reception and conception are not uniform by the isolated individual receivers. Primary group, interpersonal communication and opinion group are part of the communication process as a result the receiver's intentions also became important. Use and Gratification theory is the product of this concept. (Priest, 2010, p.38; Westerik, 2009, p. 1)

"The New Media distinctively associated with the nineteen and twenties centuries- the press, radio, and television, the cinema and the record industry-have traditionally been grouped together under the heading 'Mass Media' and their study developed as a part of the sociology of mass communication" (Bennett, 1982, p.30). At one level the term gives an explanation about the relation of media and mass but on the other level it is confusing as the term media refers to press, television, cinema etc and they are only superficially similar. For example, the relation of state with press and cinema is not the same. (Bennett, 1982, p.30). But since 1960s the long term and short term effects of media are accepted. The short term effects are due to primary processes, arousal processes and immediate mimicry of specific behavior while the long terms are the effect of, "more lasting observational learning of cognitions and behavior" and activation and desensitizationofemotional processes. (Huesmann, 2007, para. 1-13)

\section{Role of media in Pakistan}

The inherited press, with the independence of Pakistan in 1947, was weak and there were very a few rules and regulations which were equal to none. Print was the oldest means of information but due to financial and some other constraint newspapers like Roshni, Musalman and Inqallab were closed. In 1947 the first news agency the Associated Press of Pakistan was established. It became a government agency in 1961 before it was a private agency while in Dec 1972 government established Pakistab Broad Casting Cooperation. (Naseer, Katib, and Ejaz, 2010, p.3).

Despite the effects of the wars in the neighboring country, the media of Pakistan is up to the modern time period and discusses all the social and international issues and inform the public about the political and bariatric working. It brings to light the exploitations of the elite class of the country. People were more informed, in this way effected the people's perceptions and priorities. (Naseer, Katib, and Ejaz, 2010, p. 9-13).

General Musharraf initiated the free electronic media in his regime and the satellite technology added to the advancement of media. The readership reduced and viewership increased. Cheap manufacturing in 
Pakistan and import of TV in Pakistan make the TV available to all. The free electronic media was a necessity because of the Kargal war. During the war PTV due to its limited viewer ship was not able to deliver information and people turned to Zee TV and other Indian Channels in order to get the story of the other side. In 2001 and 2002 government took steps to ensure the availability of electronic media at the grass root level. (Naseer, Katib, and Ejaz, 2010, p.10-11) There were also the advent of independent TV channels. Despite the freedom of media, the conservative, religious and some big groups makes the delivery of information cautious. In this way mass media came to surface to provide information more quickly. Mass media includes newspaper, radio, Television and internet and has enormous power to change a society. (Naseer, Katib, and Ejaz, 2010, p.21).

The growing terrorism and other evils of society are not the new phenomena's. They are in this world from the time when Qabil murdered Habil and will be there till human are on this planet earth but the first largest act of terrorism was seen on September 11, 2001 and as a result the US attacked Afghanistan on the grounds that the act of terrorism was planned over there. The aftermaths of the terror activities and the war was seen in Pakistan and the bombing, looting, kidnapping, and murders increased alarmingly (Irshad, 2011, p.224-225). So Pakistan suffered, "socially, politically and militarily" (Irshad, 2011, p. 232). As it is said above that media helps in the development of public opinion that is why in such circumstances the media can unite them and educate them in a positive way. For some years there was the trend of "being the first to bring any new story" (Irshad, 2011, p.236) and the increase in the element of sensationalism. Jahangir and Nawaz (2014) stated in their research that the media in Pakistan shows $41 \%$ violence, $46 \%$ vulgarity and $65 \%$ chaos. It also contributes in $97 \%$ increase in the stress and tension. (p.97) Albert Bandura and his colleagues research on the capacity "of children to imitate what they see" (American Psychological Association, 2013, para. 1). The 15 years' research resulted in the fromation of General Scientific Advisory committee on Television and Social Behavior" in 1969. The purpose of the committee was to see the "impact of violence on the attitudes, values and behaviors of viewers". The report of the committee came with the following results in 1982: "The children may become less sensitive", "more fearful of the world around" and "behave in aggressive or harmful ways towards other" (American Psychological Association, 2013, para. 2).

PESHAWAR JOURNAL OF PSYCHOLOGY AND BEHAVIORAL SCIENCES, 2018, VOL. 4, NO. 1, 97-120 
Huesmann et al. (2003) found that the children who watched violent programs in the childhood show aggressive behavior as an adult. (p. 201) Anderson et al. (2010) also found that exposure to violent video games, "is a causal risk factor for increased aggressive behavior, aggressive cognition and for decreased empathy and prosocial behavior" (p.151). This is the reason that the children who are the future of a nation become at risk when the media does not fulfill its duties properly. But this is only one side of a coin media also has positive effects and it also struggles to provide positive images and ideas to the viewer's especially children. In such times when Pakistan was hard hit by the terrorism and the moral degradation and the children are getting images from their surrounding environment it was necessary for the media to provide alternative images. So, that children could comprehend and through their logical reasoning understand the good in humanity and their own roles in the country building.

In this regard The Little Art, a nonprofit art education organization, aims to promote literacy among the youth about media. It organizes "Lahore International Children Film Festival" and has also organized "Children's Media Network Conference" from 15$20^{\text {th }}$ December 2014 in Lahore with the project "Media Programs for Children in Pakistan". The three children programmes Burka Avenger (2013), Quaid Say Baatain (2013) and 3 Bahadur (2015)are selected. There seems to be no research done on them except Burka Avenger. The research focuses on the inequalities people faces in the country as well as the representation of the corrupt politicians and Taliban's atrocities. It shows that the 'lady in Black' has gathered the world to talk seriously about the rights and status of women in Pakistan. The study is done by the analysis of only the first episode of Burka Avenger series.

\section{Cultivation of ideas through themes}

Burka Avenger (2013) is the story of a burkua clade super heroine fighting giants the problems that occur in the town Halwa Pur and to Immu, Ashu and Mooli and their families. In Quaid Say baatain (2013) the small child Zainab try to resolve the problems she faces in her daily life by having a conversation with Quaid-e-Azam while in 3 Bahadur (2015), Amna, Saadi and Kamil resolve to free their town Roshan Basti from the tyranny of Mangue who has turned it into andher Basti and is now a picture of distress.

PESHAWAR JOURNAL OF PSYCHOLOGY AND BEHAVIORAL SCIENCES, 2018, VOL. 4, NO. 1, 97-120 
The film 3 Bahadur (2015) starts with a happy festival which talks about peace and prosperity. The song in the festival shows that the people of the town Roshan Basti are living a very happy life and they are untouched by the different evil forces. They are living in love and harmony. Every moment spent here is full of peace and happiness, Our lives are filled with happiness, No blooming flower could ever whither here. Come and enjoy colourful festival

Live in peace, Harmony and in love. (Chinoy, 3 Bahadur, 2015) As it is set in the Pakistani society, it gives the viewers a positive image about the true nature of the people of the country. It shows that the outside forces are destroying the peace loving country and they can only be curbed with courage, positive outlook of life and intelligence. The merry making in the beginning of the film is juxtaposes with the kidnapping of a child, "Stop! Where are you taking the child away!" (Chinoy, 3 Bahadur, 2015). Which hints towards the entering of an evil in the town. The film represents the struggle of good against the evil. The good which appeared strong in the beginning buried down under the evil forces with the arrival of Mangu and the assassination of the man Ahmed who shattered his plan to kidnap a child, "By silencing the voice of truth, Mangu spread fear into the hearts of all people" (Chinoy, 3 Bahadur, 2015). The evil is shown to be powerful with no one seems to be able to fight against it. It also shows that the evil does not necessarily mean that it will be of hideous face. Even the good looking man can be evil. It is the inner intentions which makes us good or evil. When Mangu fails to kidnap a kid for his heinous desires of getting supernatural power, he hides in an underground place. There he meets the king of evils Baba Balam, with a very horrible face. When Mangu says that he is hideous Baba Balam replies that there is no difference between the two as the cause of both are the same that is to have evil powers, "Your face may be better looking then mine, but our nature is exactly the same... Don't you want to harness the power of majestically forces to enslave the world" (Chinoy, 3 Bahadur, 2015). The three kids out of their curiosity visits the tower, the control house of the evil Mangu, "I am Mangu and from this day onwards I am your king! This tower is my kingdom and you people are my subjects!" (Chinoy, 3 Bahadur, 2015). The three children, the symbols of good, resolve to fight against Mangu the personification of evil as he protects the key, "the key to all evil powers" (Chinoy, 3 Bahadur, 2015). When the elders were bearing all the hardships of Mangu, the children rejected the cowardliness due to the conflict going on in their minds as, children are the embodiment of good 
and to be inactive is not in their nature. The rule of Mangue was hindering their goodness. They fought against it and came out victorious.

Burka Avenger (2013) also shows the journey of good against evil forces. The evil can be both in the physical form as well as ideological. Baurqa Avenger wants to fight both. The black face of evil is shown through the character of Baba Bandooq and his-not-to-call intelligent friends. She fights with the power of knowledge and pen against the ills created by Baba Bandooq. In the very first episode Baba Bndooq closes the school of girls and repeats the words of Vadero Pajero. According to Vadero Pajero there is no need of girls' education. He shows his patriarchal set of mind and thinks that, "what business do women have with education? They should stay at home, washing, scrubbing and cleaning, toiling in the kitchen. Whether they study or not they are going to end up making rotis in the kitchen" (Haroon and Khan, Burka Avenger, 2013). The hypocrisy of the leader comes to the limelight when he shares his secret with Baba Bandooq and says to him that the money given by the charity groups for the promotion of girls' education is in his pocket and he is not going to use it for that purpose, "Those charity fools gave me money to run the girl's school. What do they think I am? I am not going to waste money on those worthless girls. The money will stay in my pocket" (Haroon and Khan, Burka Avenger, 2013).

In the same way Quaid Say Baatain (2013) portrays inner conflicts in the mind of a little child Zainab against the negative and wrong doings of life. She faces conflicts every day and settles them. In this way good conqurers evil. In the $2^{\text {nd }}$ episode when Zainab's father tells her not to play with Sara, she questions it as Sara is a Pakistani just like her, Father: You will not play with Sara again.

Zainab: Why?

Zainab (to herself): Sara is different to me. She is my good friend." (Quaid Say Baatain, 2013)

She accepts the order of her father but the conflict in her mind led her to dream about it. In the dream she meets Quaid-e-Azam who guides her and she comes up with the realization that there is no difference between the people of this country. All the people are the citizens of the country. The caste, class and clan tradition cannot and must not divide the nation. She tells her father in the morning that everyone has same rights, responsibilities, duties and obligations.

Sara: She is a Pakistani just like us.

PESHAWAR JOURNAL OF PSYCHOLOGY AND BEHAVIORAL SCIENCES, 2018, VOL. 4, NO. 1, 97-120 
Quaid said from whichever color, caste and clan we belong to, we are the citizens of this country. We have equal rights, facilities and responsibilities. (Quaid Say Baatain, 2013)

The theme of education is presented in the Burqa Avenger (2013) in full scale especially the education of girls. Jiya in the guise of the super heroine, the Burqa Avenger, fights against Baba Bandooq. He does not like girls' education and thinks that the education will bring modern ideas and values, "Do these girls want to be modern?" (Haroon and Khan, Burka Avenger, 2013). Baba Bandooq presents the evil force in the small town Halwapur. He can aptly be compared to the non-state actors in Pakistan especially those who were against the education of girls' in the valley of Swat. As Malala (2013) herself narrates in her autobiography I Am Malala: The Girl Who Stood Up for Education and was Shot by the Taliban, that the girls education was banned in Swat by the Taliban. It was announced that, "there should be no education for women even at girls' madrassas" (p. 97). Malala fights against this supression with pen and told to the world about the realities and austerities of them with the name Gul Makai, "Hai Kakargave me the pseudonym Gul Makai, which means 'cornflower' and is the name of the heroine in Pashtun folk story" (p.130). In the same way the burka in the series is not a sign of oppression but a means to help the society and Jiya keeps her own identity separate from the personality of the super heroin and tells the children to be determined in their lives and never give up education, "Do you know what is the best weapon against adversity? Education. Don't ever let anyone stop you from gaining knowledge. Whether girl or boy education is your right" (Haroon and Khan, Burka Avenger, 2013). The Quaid Say Baatain (2013) is set in the educational environment with the focus on all the moral values of the society. In one of the episodes the characters struggle to fight against a conflict. Ali decides to leave study and thinks that there is no need of education, "I am going for circus. Study appears difficult to me and there is no fun. There will be much fun in the circus and I will get money also" (Iqbal, Quaid Say Baatain, 2013).

Zainab tries to convince him and tells him that Quaid will not like it but he does not listen and when he sees all his class fellows moving forward from him he becomes worried. At that time Quaid tells him that education has helped them to lead a successful life. If we do not get education, we will not be able to go with the faster world, "Kia sirf parhne ki waja se Zainab aur Sara mujhe se intne age chalegae?" (Iqbal, Quaid Say Batain, 2013). That is why Burka Avenger and children fight for 
education against Baba Bandooq. Though the words spoken by Ashu are a little exaggerated because children of her age usually do not know about these complex issues but the message conveyed carried a great weight. It is a famous saying that you educate a man you educate a man. You educate a woman you educate a generation. That is why Ashu says, "We need education...It is our right. If mothers are not educated the future generation will also remain illiterate" (Burka Avenger, 2013). The episode also shows that a small bulk of people and their activities give a negative impression of pakistani society otherwise the struggle of the people of Halwapur showed that they are not against girls' education that is why Haroon in his consert says that the rejection of the will of the few by the people of the town is a well appreciated act, "I am pleased to see that when faced with adversity you fought with determination" (Haroon and Khan, Burka Avenger, 2013).

The corruption of the society is presented and brought to light through the thugs of Mangu in 3 Bahadur (2015)as they are earning the money through water supply of the town by an illegal means. According to Nye corruption is a "behavior which deviates from the normal duties of public roles [it also includes] misappropriation (illegal appropriation of the public resources..." (Heidenheimer and Johnston, 2002, p.8). The thugs of Mangusieze on the rights of the town by using the water which is a public property while the real beneficiaries of the town suffer water shortage. The people are living in a very precarious condition. Kamil, Saadi and Amina open the water supply once they find out the control system. It shows that united we can beat the power of a few. In Burqa Avengers (2013) the corrupt politicians are presented through the character of Vadero Pajero who works for Baba Bandooq. Vadero Pajero is only interested in money making. He even doesn't take care of the polio vaccine which is a grave matter of the country and does not take it seriously. When the polio has been stolen by Baba Bandooq and news caster asks him about the step in the absence of polio vaccine, he turns ablind eye to his inabilities and says that the children must not catch polio virus now, "News Caster: The polio vaccine provided by the government has been stolen ...

Mayor Vadero Pajero: Er, as you see, we tried our best...Well Madam! All we can do now is pray that no child catch polio" (Haroon and Khan, Burka Avenger, 2013). 
This picture of a mayor is a caricature of the politicians of Pakistan who do not have any concern about the common public and are busy in their own leisures.

Corruption is shown in the education through Zainab the character of Quaid Say baatain. She gets the opportunity of cheating and cheats, but her conscience does not allow her to be calm "Zainab: I have done only once. It is not that much bad thing. Uff! What has happened" (Iqbal, Quaid Say Baatain, 2013). Within the same episode it is also made clear to the children that ususlly in our lives we do some acts which appear small at that particular time but then it becomes our habit and we cannot differentiate between right and wrong. That is why evil must be curbed in its bud as Quaid says to Zainab,

"Zainab! Sometimes we come across such a situation that it appears easy to take a wrong step. And then slowly and gradually the evil spreads in the while society. And then it does not appear evil" (Iqbal, Quaid Say Baatain, 2013).

Quaid advices her to try hard in her life and never lose hopes and hardwork is important in life, "Zainab! There is no alternative for hard work" (Iqbal, Quaid Say Baatain, 2013). As a result, she confesses in front of her teacher about her cheating in the paper, "I know I have made a mistake and I am really ashamed" (Iqbal, Quaid Say Baatain, 2013). The Quaid has clearly told her that one little step would lead to other steps and if it is going in the wrong direction, it will lead to destruction. That is why she takes a right step and gets an appreciation from her teatcher, "Zainab! Tum ne ajk bohat mushkil kam kia hai apni ghalati ka aeteraf", "Zainab! You have done a really difficult job: The confession of your mistake" (Iqbal, Quaid Say Baatain, 2013).

The programs also direct the attention of the viewers to another grave matter which has made the root of the country very weak and that is lack of tolerance. The problem and issues of minority, the class, caste and gender issues are very beautifully and innocently presented. Through selection of vegetables like Bengan and thende. The fight of Ali and Sara is juxtaposes with the intolerance among the people of the country on social, religious and political level. Ali breaks his friendship with Sara only on the ground that she does not like what he likes and Sara also puts her friendship at stake just because their ideas does not match, Sara (to Zainab): Then you make a friendship with this Bengaan boy. Ali (to Zainab in anger): No! I cannot become a friend of a tinde lover." (Iqbal, Quaid Say Baatain, 2013).

PESHAWAR JOURNAL OF PSYCHOLOGY AND BEHAVIORAL SCIENCES, 2018, VOL. 4, NO. 1, 97-120 
Quaid then relates this conflict to the intolerance present among the four provinces of the country. Everyone will left alone and will grow feebler and feebler and hence helpless. The unity of the nation is in the tolerance and acceptance of differences and conflict in opinion. Lack of unity will divide the nation and the existence of the country will be in danger. Quaid say,

It is very sad to say that we are not ready to listen to the view of other. One day there is a basis of faith. In this way if everyone considers that he/se is right only then everyone will turn away from one another., and in the last we all will leave alone (Iqbal, Quaid Say Baaatain, 2013).

The concept is very clearly presented through the blue red, and yellow badges in the Burka Avnger (2013) and has given a great message that the apparent slight differences must not come as a hindrance in the unity of the people. The apparent differences become a danger due to the opportunistic behavior of the evil minded people. They blind the perception of the people and turn them against one another to fulfill their own evil design just as Baba Bandooq in the story wants to destroy the unity of the inhabitants of the Halwapur who used to live together without any discriminations, "Alag alag nuktoo nwalen yahan sub saath hi kheltenhai", "Here people with different marks play together" (Haroon and Khan, Burka Avenger, 2013). He has a motive for occupying the town. He leaves his men in the town who turn one against the other and all of the sudden they become aware of the differences, "When one group will become more powerful it will maltreat the other and will throw that group out of Halwapur. And when the dominant group will reduce in number then we will rule over them" (Haroon and Khan, Burka Avenger, 2013).

Along with the evil forces sometimes the elders behavior also strengthen these boundaries. even within a nation. Zainab's father tells her not to play with Sara, "Go inside. You will not play with Sara from now on (Iqbal, Quaid Say Baatain, 2013) and the innocent Zainab questions it, "Why??" (Iqbal, Quiad Say Baatain, 2013). The continuous feeding of the same concept will add her to the same concept but she resloves it through her own mind and reason. The parents of Amina, Saadi and Kamil also do not like the courage of their children to fight Mangu and discourages them, "Despite their powers, they are still children" (Chinoy, 3 Bahadur, 2015). In this why they want to remain in a subordinate condition and does not want their children to exceed the limits. But later, Amina father persuades the parents of Kamil and Saadi to accept their bravery, "We may not trust their power but we should trust our 
children...If we squash their spirit today, then how many more will continue to suffer this tyranny" (Chinoy, 3 Bahadur, 2015).

In most of the programs the children are just the side characters, completing the family or the subject of dispute but in these programs the children are presented the roles with capability to think and protect themselves. The children especially in Burqua Avenger (2013) and Quaid SayBaatain (2013) struggle against all the negative powers and through their positive attitudes bring changes in the society. The 3 Bahadur brings back the light and peace of Roshan Basti after an intense fight with the evil, "We won! We won! We defeated Mang" (Chinoy, 3 Bahadur, 2015). In Quaid Say Baatain (2013) Zainab resolves all the common issues which we face in our society and either ignore them or lead to some disputes. In episode six after a great storm a fallen tree blocked the way of many people of a street and everyone passes by the tree thinking that it is not possible for him to do it alone, "Kuch karna chaheye is darakht ka magar akhele kia karun", "Something must be done to this tree but what to be done alone" (Iqbal, Quaid Say Baatain, 2013). Zainab takes the first step and solves the issue by asking everyone to work together, "Ab hum sub mil k is kohataenge. "Now we will remove it together (Iqbal, Quaid Say Baatain, 2013).

Along with these themes it appears that in all the three programs the lead characters are girls. In 3 Bahadur (2015) though Sara, Saadi and Kamil equally works but it is mostly Sara who helps her friends to escape the dangerous situations. Even Deenu Chacha, who gave extraordinary powers to the three kids, accepts the courage of Amina, "You rescued Kamil from tower, overcome the speedy fan and raced the buses to save those children" (Chinoy, 3 Bahadur, 2015). In Burqa Avengr (2013)it is the girl Jiya who teaches at school and fights not only for the rights of girls but also the implementation and safeguard of the true moral values, "A tragic incident left me orphaned as a child. A kind man and his wife gave me loving home. I fight against the forces of tyranny and ignorance" (Haroon and Khan, Burka Avenger, 2013). She does not fight in the usual manner with sword or bitter words but scientifically and psychologically through knowledge that is book and pen as oppose to the opponent who build different things to break her but in vain as all the powers are the inner powers, "The art of fighting with books, pens and advanced acrobatics" (Haroon and Khan, Burka Avenger, 2013).

The small child Zainab is a leading character in the Quaid Say Baatain (2013) and shows her concern about all the problems and the 
values which has become part of our society and culture. She cannot accept, when Ali tells stops her and Sara from playing cricket on the basis of his stereotypical opinion about the cricket game, she does not like the corruption of milkman and the stealing of electricity, she raises her voice against the VIP culture and rejects the influence of terrorist activities in the country,

"Is cricket really the game of boys only?, Quaid! What is this happening?, Will I select too?, Why you stopped the traffic?, What is this happening" (Iqbal, Quaid Say Baatain, 2013).

Despite all these facts children are actually the representation of all the children of Pakistan without any gender discrimination and represent their ability to guide and solve the issues and the talent present in them. The talent which can be utilized in positive ways.

These repetition of themes cultivate in the mind of children the ability to better use their abilities and make them conscious to the fact that control of emotion and use of brain is necessary in a particular situation. One must not lose ones control of himself/herself especially in anger as it blinds the ability of a person to think. In 3 Bahadur (2015) Saadi and Kamil become anger and lose their temper and forget the advice of DeenuChaha, "Be careful not to make any impulsive mistake. Your opinion should be your strength, not your weakness. No matter what happens do not let your anger cloud your judgment" (Chinoy, 3 Bahadur, 2015). Saadi then realizes his mistake and with open mind find a way to defeat evil. He realizes that his fight is not against evil but, "with the evil that gives power to people like him" (Chinoy, 3 Bahadur, 2015). This shows that power is not to conquer other or surpass. It is to get the love of other and distribute the equal opportunities. Power is to be good for all. Power is that other gets peaceful environment because of you. Power is to be with your good, "Violence is never the answer to anything", "Androonisakoon". (Haroon and Khan, Burka Avenger, 2013). The content of the programmes also show that flexibility is necessary in life. Everyone must respect the opinion of other without any grudges. Sometimes elders are wrong due to a particular ideology working on them or cultural and social pressure. Zainab father and a traffic police in Quaid Say Baatain (2013) does not hesitate to change their opinion once they find that they are wrong.

The explanation showed that Cultivation of ideas takes place through repetition of different ideas in the programs. The repetition makes an impression on the mind of an individual and become the part of its 
personality. The TV programs are presented in the time period when the Pakistani society is under the the influence of the terrorism and social and moral corruption. The continuous appearance of these acts in the society and the constant feeding of these news by different TV channels and films can lead to the construction of only negative image on the mind of the children who have the ability to grasp more rapidly. The positive images and content of these three programmers will create a relation of the children with the society. As it is said, "The illumination of the ...invisible relationships of life and society has always been the principal function of storytelling" (Gerbner, 1986, p.3).

\section{Cultivation through different media sources and styles}

Media is responsible for the children's character building and the three recently released programs have great popularity among children and the themes of corruption, good and evil, education etc are presented in the three programs in different styles. In the 3 Bahadur (2015) the three children are in a fight against the evil Mangu who is dwelling inside their town. Burqa Avegers fights against the wrong doers by taking another identity. So that she can live her common life and Burqua Avenger be the superheroin of the children and viewers. Quaid SayBaatain(2013) shows the issues by discussing it with Quaid. In this way through different styles and variety in their representation same themes are presented with the defeat of evil and the success of good at the end, "the Repetition patterns of messages, and images form a main stream of common symbolic environment" (Gerbner, 1986, p.3).

Nowadays the means to get the programs are divers and children can watch them through television, internet, or in Cinema. The most preferred medium of entertainment for children is television but with the advancement of society children are moving towards internet which is an essay access for desired material.

Along with the repetition of the themes in the three programs are presented in Cinema and TV and available on Youtube very easily. The team of 3 Bahadur (2015) and Burka Avenger (2013) have made a video game as well. According to the different deliver systems help in the penetration of the desired pattern of life, "For most viewers, new types of delivery systems such as Cable, Satellites, Cassettes signals even further penetration and integration of established viewing pattern into the everyday life" (Gerbner, 1986, p. 2).

PESHAWAR JOURNAL OF PSYCHOLOGY AND BEHAVIORAL SCIENCES, 2018, VOL. 4, NO. 1, 97-120 
All the programs are against evil and fighting hard in order to give a positive message to the children that the wrong doers can be punished only through will, hope and courage and that children are not the passive watchers and they are also the part and have the ability. The local superheroes living among them and are therefore role model for them to fight the gloomy environment around them instead to be a prey to it. "Therefore, the focus of cultivation analysis is not on what this or that campaign may achieve but what all complain and up giants" (Gerbner, 1986, p. 6).

\section{Children as active viewers}

Viewers and the target population that is children are passive as claimed by the cultivation theory (1986), "Passive viewers being programmed from birth" (p.7). But according to Meyer and Anderson, "For most history in mass communication, content has been seen as a silver bullet shot from a media a gun to penetrate the helpless audience. Media audience participate actively in the mediated communication. They construct meaning from the message they perceived. Meaning is not delivered in the communication process rather constructed with it" (2009, para. 5). In the theQuaid Say Baatain (2013) Zainab is presented as an intelligent viewer she rejects the opinion of Ali and tells him that anything presented on the TV must not be taken as true. One should use one's mind and understand it, "Mr. Macho Man says it does not mean he speaks the truth" ( Iqbal,Quaid Say Baatain, 2013). While in Burqa Avengers and the Giant Slingshot (2013) Baba Bandooq makes use of media and presents a superhero infront of the viewers, when Mooli and Immu accept it as reality Ashu objects it and says, "Moli, this could all be a scam, you know?" (Haroon and Khan, Burka Avenger, 2013). It shows that the audience are not passive but they interpret, and understand the media content according the surrounding they are living in. Social Action Theory says that, "Any meanings offered by media content get mingled with these other meanings" (Schoening, 1995, para. 8).

From the humanistic point of view like Abraham Maslow and Carl

Rogers. "A person can choose to take the kinds of actions that will help him or her to maximize her talent and potential...have the power to control and direct one's own life" (Bruno, 2002, p. 203). In the APS episode in the Quaid Say Baatain (2013)Zainab cannot bear the images presented on the television about the APS attack and she starts crying, "Ye sub kia ho rahahai?" (Iqbal, Quaid Say Baatain, 2013) and falls asleep. In the dream 
she gives a stong message to Quaid and herself "Ap k Pakistan ko qaim rakhna hamari zimidari hai aur hum ye kar k dekhayenge" (Iqbal, Quaid Say Baatain, 2013). In this way Zainab interprets and comes to a conclusion fit for her situation. The images of the rash and bloody deed throws its viewers into panic but Zainab keeps her spirit high. The viewers, "can also attend to content in ways that make sense more for the situations in which they are acting than for any meaning suggested by content" (Schoening, 1995, para. 17).

\section{Children as passive viewers}

As children get influence from the surrounding environment and try to mimic it. The presentation of the real life like situation and the question present in the mind of the children presented through dialogues are not only for communications but for construction. The children get the answers present in their minds. The deliberate presentation of situations and the questions and answers are therefore technique to influence the the thinking of children. The episode about the eradication of polio reveals the face of the people having evil designs for the country through dialogues. The arguments between Baba Bandooq and Mr. Sheikh make it clear to the viewers that there are some people who have negative intentions for the country,

Baba Bandooq: Stay away from Halwapur...And there is no need to bring any more medicines.

Mr. Sheikh: No, years ago my family listened to an ignorant fool like you and never had me vaccinated against polio as a child. I fell victim to this terrible virus. But I never lost hope. I have devoted my entire life to ensure that no parent makes this mistake.

Baba bandooq: Listen carefully! We stole the polio vaccine box and hid them in the cocktower. Now I will sell these precious vaccines and make a brand new Doomsday machine" (Haroon and Khan, Burka Avenger, 2013).

They are provided all the situations clearly and along with the cultivation they are left with the result to either get the influence of the character or interpret it according to their own situation.

In the episode the Burka Avenger and the Giant Slingshot (2013) when the comic superhero is presented as a great, brave man Mooli immediately gets the inspiration to be a hero while the reaction of Ashu was opposite she was thinking it a drama while Ali in Quaid Say Baatain blindly

PESHAWAR JOURNAL OF PSYCHOLOGY AND BEHAVIORAL SCIENCES, 2018, VOL. 4, NO. 1, 97-120 
imitates her his favorite superhero. He even does not hesitate to do a deadly stunt,

"Mr. Macho Man is my favorite Hero and he says if we will obey his every words then we can also do everything... Now I will show this stunt" (Iqbal, Quaid Say Baatain, 2013). This shows that there is the possibility of the viewer to be passive.

The programs accept as well as cultivate the reasoning capabilities of the viewers. The children usually do not accept the things happening in their surrounding but the effect of them cannot be denied. As it is accepted that children interpret the elements present in their surrounding but according to the psychological theories the experiences of life stores in our unconscious influence our personalities and decision making. They think that there are two learning processes which can effect the personality development that is operant conditioning and observational learning. (Bruno, 2002, p.203) "Operant Conditioning takes place when behavior is shaped by reinforces. Reinforcement increase the probability of occurrence of a given class of behavior. Observational learning takes place when an individual imitates the behavior of a role model" (Bruno, 2002, p.203-4).

They are active and are influenced by other factors like parents, environment and the other preferences. So the cultivation of media have not got the required result but according to Gerbner (1986), "A slight but pervasive (e.g, generational) shift in the cultivation of common perspectives may alter the culture climate and may upset the balance of social and political decision-making without necessarily changing the observable behavior" (p.9). Only a slight change is enough to bring a change in a society's behavior because it usually takes only a few degrees change in temperature and the result is an Ice Age. (Gerbner, 1986, p.9)

\section{Conclusion}

Media importance therefore, cannot be denied. The cultivation is a process through which media is feeding the positive social and moral values in children. Media if go on the same track can be a guid in their life. Pakistani media which was and is under the influence of sensationalism for the last few years is trying to change its course of action and comes up with creative and informative contents. The drama serial Udaari, Khuda Mera Bhi Hai are some of the very recent examples. Children watch cartoons with more interest but as there were no local cartoon programs interesting enough to catch the attention of the viewers, they are moving towards the Indian or Western channels or programs like Dorymon, 
Superman, Spiderman, Batman, and Tom and Jerry etc. These programs have Westren setting and Pakistani children do not feel at home with them but get their cultural and ideological impression. Burka Avenger (2013),3 Bahadur (2015) and Quaid Say Baatain (2013) are set in Pakistan and have the Pakistani culture. The research proves that the content of the programmers give the message that through logical reasoning and intelligent thinking all the problems can be solved and peace and harmony can be restored. The study also proved that through repetition of themes and use of all sources like T.V, Cinema, Videogames and Internet the media wants to cultivate in the mind of children the positive images present around them and in this way direct their attention away from the negative influences. It also shows that the viewers are most of the times passive due to the repetition of message in front of them. They cannot distinguish between reality and falsehood. That is why it is apt to say that"The educational and informative roles of the media can help to make the country strengthen and stabilized. It can inform the informative and make the positive approach of the people of the society" (Naseer, Katib, and Ejaz, 2010, p.28).

\section{References}

American Psychological Association. (2013). Violence in the MediaPsychologist Study TV and Video Game Violence for Potential Harmful Effects. Retrieved from: http://www.apa.org/research/action/protect.aspx

American Psychological Association. (2013). Violence in the Media: Psychologist Study Potential Harmful Effects. Retrieved from: http://www.apa.org/action/resources/research-inaction/protect.aspx

Anderson, C. A., Ihori, N., Bushman, B. J., Rothstein, H. R., Shibuya, A., Sawing, E. L., et al. (2010). Violent Video Game Effects on Aggression, Empathy, and Prosocial Behaviour in Eastern and Western Coutries: A Meta Annalystic Review. American Psychological Association,136(2),151-173.

Bennett, T. (1982). "Theories of Media, Theories of Society". In Culture, Society, and the Media. Ed. Michael Gurevitch et al. London: Methuen.

Brennen, B. S. (2013). Qualitative Research Methods for Media Studies. NewYork:Routledge.Retrievedfrom:https://books.google.com.pk /books?id=iRcQ1 JgZPZoC\&printsec $=$ frontcover $\# \mathrm{v}=$ onepage $\& \mathrm{q}$ $\& \mathrm{f}=$ false

PESHAWAR JOURNAL OF PSYCHOLOGY AND BEHAVIORAL SCIENCES, 2018, VOL. 4, NO. 1, 97-120 
Bruno, F. j. (2002). Psychology: A self Teaching Guide. New York: John Wiley and Sons.

Chinoy, S. O., Iqbal, S., Seja, J. and Chinoy, S. O. (2015). 3 Bahadur. Pakistan: Waadi Animation

Chun, W. H. K. and Keenan, T. (Eds.). (2006). New Media, Old Media: A history and Theory Reader. New York: Routledge. Retrieved from:

https://books.google.com.pk/books?id=jZoXKMOeBowC\&print $\mathrm{sec}=$ frontcover $\# \mathrm{v}=$ onepage $\& \mathrm{q} \& \mathrm{f}=$ false

Cresswell, J. W. (2003). Research Design: Qualitative, Quantitative and Mixed Method Approach (2nd ed.). London: SAGE Publications. Retrievedfrom:https://isites.harvard.edu/fs/docs/icb.topic133458 6.files/2003_Creswell_A\%20Framework\%20for\%20Design.pdf

General Assembly Resolustion. (1990). Covention on the Rights of Child. United Nations Human Rights Office of the High Commissioner. Retrievedfrom:http://www.ohchr.org/en/professionalinterest/pag es/crc.aspx

Gerbner, G., Gross, L., Morgan, M. and Signorielli, N. (1986). Living With Television: The Dynamics of the Cultivation Process. In Perspectives on Media Effects. Bryant, J. and Zillmann, D. (Eds.). Hillsdale, N. J. :Lawrence Erlbaum Associates. Retrieved from: http://web.asc.upenn.edu/gerbner/Asset.aspx?assetID=1644

Hassan, A., and Daniyal, M. (2013). Cartoon Network and Its Effect on the Behavior of the School Going Children: A Case Study of Bahawalpur Pakistan. International Journal of Management, Economic and Social Science, 2(1), 6-110.

Heidenheimer, A. J. and Johnston, M. (2002). Political Corruption: Concepts and Contexts (3rd ed). New Brunswick: Transaction Publishers

http://go.galegroup.com/ps/anonymous?id=GALE\%7CA287705163\&sid $=$ googleScholar\&v=2.1\&it=r\&linkaccess $=$ fulltext\&issn $=181964$ $62 \& \mathrm{p}=\mathrm{AONE} \& \mathrm{sw}=\mathrm{w} \&$ authCount $=1 \&$ is AnonymousEntry $=$ true

http://www.unicef.org/pakistan/media_6667.html

Huesmann, L. R. (2007). The Impact of Electronic Media Violence: Scientific Theory and Research. J Adolesc Health, 41(6). Retrieved from: https://www.ncbi.nlm.nih.gov/pmc/articles/PMC2704015/

Huesmann, L. R., Titus, J. M., Podolski, C. L., and Eron, L. D. (2003). Longitudinal Relation Between Children's Exposure to TV

PESHAWAR JOURNAL OF PSYCHOLOGY AND BEHAVIORAL SCIENCES, 2018, VOL. 4, NO. 1, 97-120 
Violence and Their Aggressive and Violent Behavior in Young Adulthood: 1977-1992. American Psychological Association, 39(2), 201-221. Retrieved from: https:/www.apa.org/pubs/journals/releases/dev-392201.pdf

Irshad, M. (2011). Terrorism in Pakistan: Causes and Remidies. The Dialogue. Department of Management Sciences. Qurtaba University, Peshawar, 6(3), 225-241.Retrieved from: http://pgil.pk/wpcontent/uploads/2014/04/Dialogue_July_September2011_224241.pdf

Jahangir, S. F. and Nawaz, N. (2014). Effects of Media (Television) on Mental Health. FWU Journal of Social Sciences, 8(1), 97-107. Retrieved from:http://sbbwu.edu.pk/journal/FWU_Journal_Summer2014,V ol.8,No.1/15Effects_of_Media_(Television)_on_Mental_Health. pdf

Khan, I. (Feb 23, 2014). Pakistan Most Terror-Hit Nation. Dawn. Retrieved from: http://www.dawn.com/news/1088864

McDougall, J. (2012). Media Studies: The Basics. New York: Routledge. Retrievedfrom:https://books.google.com.pk/books?id=Qfw9obC ga14C\&printsec $=$ frontcover $\# \mathrm{v}=$ onepage $\& \mathrm{q} \& \mathrm{f}=$ false

Naseer, M., Katib, K., and Ejaz, S. (2010). Role of Media in Pakistan. International Islamic University Islamabad. Retrieved from: https://www.scribd.com/doc/30767602/Role-of-Media-inPakistan

Noorani, D. and Iqbal, T. (2013). Quaid Say Baatain. In Rashid, H. : UnicornBlackProduction.Retrievedfrom:https://www.youtube.co $\mathrm{m} /$ watch? $\mathrm{v}=7 \mathrm{w}$-ao0X1Mcs

Priest, S. H. (2010). Doing Media Research: An Introduction. Los Angeles.

Qayyum,S., Malik, N., Iqbal, M. M. A., Anwar, H. N. and Sohail, M. M. (2013). Exposure to Violent TV Programs and Its Effects on Siblings Aggressive Behaviour: Parent's Perceptions. International Journal of Business and Social Sciences, 4(7), 205212.

Rashid, H., Zafar, A., Naseer, A., Ahmed, K., Ghias, S., Fancy, N. H., and Naqvi, A. and Rashid, H. and Khan, U. Z. (2013). Burka Avenger. In 
Rashid,H.Pakistan:UnicornBlack.https://www.youtube.com/watc $\mathrm{h}$ ? $\mathrm{v}=\mathrm{tHwHayZZFiw}$

Saleh, L. (2015). The Burka and Beyond: Burka Avenger, Muslim Women, and Pakistani National Identity. CPSA Annual Conference. Retrieved from: https://www.assocsrv.ca/cpsaacsp/2015event/Saleh.pdf

Schoening, G. T. (1995). The Meanings of Behaviour and the Meanings of Media: Reassessing the Potential for Accommodation Media Ethnographies to Study Significant Sicial Variables. Electronic Journal of Communication, 5(1).

Westerik, H. (2009). The Social Embeddedness of Media Use: Action Theoretical Contributions to the Study of TV Use in Everyday Life. New York: Mouton de Gruyter.

PESHAWAR JOURNAL OF PSYCHOLOGY AND BEHAVIORAL SCIENCES, 2018, VOL. 4, NO. 1, 97-120 